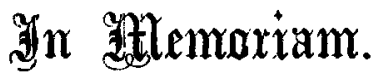

CONOLLY NORMAN, M.D. Dubl. (Hon. Causâ); FELLOW AND VICE-PRESIDENT, ROYAL COLLEGE OF PHYSICIANS OF IRELAND; MEDICAL SUPERINTENDENT OF THE RICHMOND DISTRICT ASYLUM.

IT is with a very real sense of personal as well as of professional loss, and with the deepest regret, that we have to record the death of Conolly Norman, which took place suddenly on the afternoon of Sunday, Feb. 23, 1908.

DR. Norman had returned from a holiday in the country only five days before the sad event took place, seemingly in good health and the best of spirits, and to all appearances he had quite recovered from the severe attack of influenzal fever and bronchitis which had prostrated him in Christmas week and had confined him to his bed during the subsequent three weeks. He had resumed his official duties at the Asylum, and had received, on the Friduy before his death, the hearty welcome of his staff and the congratulations of his Committee.

On Sunday he spent over two hours in the Asylum, and returned home for luncheon, of which he partook with his usual appetite, and afterwards left his house with the intention of paying a short visit to his friend Sir Thornley Stoker. He walked about fifty yards, when he was seen to stagger and fall. Kindly aid and medical skill were almost immediately at hand, and Dr. Cullinan, his Assistant Medical Officer of the Asylum, did all it was possible to do for him, but all to no purpose, as death was instantaneous. Within a quarter of an hour he was carried home a dead man, whence he had gone forth "a living spirit." No more striking instance has ever occurred of the truth of the well-known saying-" in the midst of life we are in death." The whole incidents of the terribly tragic end of one of the most highly respected physicians and citizens of Dublin gave a shock which will never be forgotten, and awakened throughout the City an amount of intense and pathetic interest. 


\section{In Atemortam.}

At his funeral, on the 26th of February, one of the largest concourses of friends, and of representatives of every class and grade of society, ever seen in Dublin, bore testimony to the profound sympathy with his sorrowing widow which had been aroused, and to the acute sense of the irreparable loss the wide circle of his friends, the medical profession, and in particular his special branch of psychology, had suffered by his death-a loss which will be deplored throughout Ireland and wherever mental science is studied.

Dr. Conolly Norman had suffered for some years from attacks of angina pectoris, and it was in one of these the heart stopped.

At the time of his death Conolly Norman was VicePresident and Censor of the Royal College of Physicians of Ireland, of which he had been a Fellow since 1890. In 1907 the University of Dublin, in recognition of his professional eminence, had conferred on him the distinction of the honorary degree of M.D. ; and last September he went as the accredited representative of both the College of Physicians and the Royal Academy of Medicine in Ireland to attend the meeting of the Medico-psychological Congress at Amstcrdam. His reputation and his personality pointed him out as the greatest of the specialists representing the British Isles at that Congress. This was the reason why he was entrusted with one of the most important resolutions at the final meeting. It may be worth while mentioning a little incident which occurred at the opening meeting, when the distinguished visitors' names were being discussed by the members : To the question, overheard-" Whom have we got from England?" the answer came-" I do not know, but we have Conolly Norman from Dublin "-a straw will show which way the wind blows.

To the special study of mental disease Conolly Norman applied himself early in his medical career, and it was the dream of his life to advance it, by every means in his power, to the high position it has now attained. He brought to his aid a cultured, intellectual, and well-read mind-versed in French, German and Italian literature-and he exercised by his pen and incisive speech a wide influence in the 


\section{En ttemoriam.}

advancement of the study of psychiatry. His principal writings appeared in connection with the Medico-psychological Association, of which he was an active member, and a past President (in 1894-5), and lately Local Secretary for Treland. He was also joint-editor of the Jounal of Mental Science up to the day of his death, and so interested was he in its welfare that so lately as the 18th of January, a day or two before he left for change and rest, he was engaged in matters connected with that journal.

Many contributions from his pen were read before the Royal Academy of Medicine, and published in this Journal, dealing not only with matters of psychological interest, but also with pathology and general medicine. Among the latter it will suffice to point to two most valuable communications, which stamped him as a diagnostician of keen insight, a physician of therapeutic skill, and an ardent exponent of sanitary science. The subjects exhaustively and scientifically dealt with were- "An Outbreak of Dysentery" (1886) and "The Clinical Features of Beri-beri" (1899), both of which rare diseases had occurred in the Richmond Asylum.

These papers not only aroused an unusual stir and interest in medical circles, but they exercised a far wider and beneficent effect in the condemnation of the overcrowding of the insane, and in the subsequent very extensive structural alterations in the buildings and grounds of the Asylum.

In addition to his many scientific and literary studies in psychiatry, he was one of the most successful and practical exponents of clinical instruction in lunacy.

It was during his term of office as Resident Medical Superintendent of the Richmond Iunatic Asylum that certificates in clinical lunacy became a necessity for candidates for the Degree in Medicine in the University of Dublin, and it was largely owing to his wide-reaching influence that the patients were allowed to be utilised for such purposes under his personal supervision. To these clinical courses he devoted much time and energy, and they were highly and justly appreciated by his successive classes.

Commencing in 1874 as Assistant Medical Officer at Monaghan Asylum, where he worked for seven years, Conoluy 


\section{In ftemoriam.}

Norman was appointed Medical Superintendent of Castlebar Asylum the following year-1882 - and in 1885 he returned, as Superintendent, to Monaghan Asylum. In 1888 he was appointed by Lord Aberdeen - then, as now, Lord Lieutenant of Ireland-to the Richmond District Asylum, in succession to the late Dr. Lalor, and here he spent his last twenty years of service.

If it was a work near his heart, it was one of great anxiety and worry, as, owing to his keen desire to improve the calamitous state of the poor insane in which he found them, and to render their lives endurable, he not infrequently found his views and plans of reform opposed by members of his Committee on the question of finance, and his hands tied for want of funds to carry them out. Nothing daunted, he strode straight on in the path of honourable enthusiasm and beneficence, with the result that some of those who had opposed him became his supporters, as they always were his admirers, and he had the supreme satisfaction of seeing the Asylurm placed in the forefront of all such institutions in the country, and of receiving, only two days before his death, the hearty welcome on his return of every member of his staff and the congratulations and good wishes of his Committee. It was no wonder therefore that, in the words of the Chairman of the Committee, spoken at a meeting specially convencd. the day following his funeral, "Dr. Norman's sudden death has thrown a gloom over the whole institution, and has caused genuine sorrow to us all; to the members of the Joint Committee, who recognised his great ability; to his medical colleagues, whose interests were his constant care; and to the attendants and nursing staff, who certainly owe to his personal exertions the important status which they now occupy, and which is the direct result of the special training he secured for them ; and to our patients." The Chairman proceeded: "I have been eleven years a member of this Board, and I can testify that the one great aim of Dr. Norman's life has been the care of the afflicted people committed to bis charge. To that task he directed all his great medical skill, his ripe experience, his humane judgment, and therein he succeeded in a measure far exceeding all his predecessors." The contrast which the speaker drew 


\section{In ftentoriam.}

between the Asylum twenty years ago and now was most striking. He showed how that, from being a prison for the offenders against society, where restraint and repression were proportionate to the violence and gravity of the disease, it was now transformed into an hospital for the alleviation of the suffering ones and for the cure of the sick. "It is also a hive of industry, where the bodily strong find occupation and relief from their mental weakness. Surely is a man to be judged by his work, and this life-long work of DR. Norman compels our unstinted admiration. It will remain a lasting testimony to his great genius and ability as a humane administrator and physician of the insane."

Thus may the curtain fall upon his public life and his professional and scientific career: but, as to his private life in his home, where last year he celebrated his silver wedding with his loving and devoted wife-who was ever his helpmate and comforter in the many trying and anxious years of his life, and who so ably and practically seconded all his schemes for the bettering of the female patients in the Asylum, and the brightening of their surroundings-we must be silent. We can only respect the sorrowing solitude of his widow while we tender her our heartfelt sympathy.

For ourselves we can but look back upon memories full of pleasurable greetings, genial intercourse, hospitable entertainments, and an ever-present sense that in Conoluy Norman's company we were in that of a good and Christian man, a tender and sympathetic heart; upon whose words and actions we could implicitly rely. His presence is no longer with us, his place we cannot fill, but his example and life will help us to be better men, and to aim towards the goal he has reached, and to receive the like reward-" Well done, good and faithful servant, enter thou into the joy of thy Lord."

J. M. F. 